\title{
SYNTHESIS OF NB/MCM-48 MATERIAL USING RICE HUSK ASH AS SILICA SOURCE WITH DIFFERENT SI/NB MOLAR RATIOS
}

\author{
Síntese do material Nb/MCM-48 usando cinzas da casca de arroz como \\ fonte de sílica com diferentes relações molares Si/Nb
}

\author{
Victor de Aguiar Pedott ${ }^{1}$; Iemedelais Bordin ${ }^{1}$; Carolina Elisa Demaman Oro ${ }^{1}$; \\ Ricardo Jorge Macieski'; Diego Ivan Petkowicz²; Diana Exenberger Finkler²; \\ Rogério Marcos Dallago ${ }^{1}$; João Henrique Zimnoch dos Santos ${ }^{3}$; Marcelo Luis Mignoni ${ }^{* *}$
}

\footnotetext{
${ }^{1}$ Department of Food and Chemical Engineering, URI Erechim. v.a.pedott@gmail.com; bordiniemedelais@hotmail.com; carolinae.oro@hotmail.com; ricardojmacieski@gmail.com; dallago@uricer.edu.br; mignoni@uricer.edu.br.

22Marina Tecnologia LTDA.diego_petkowicz@yahoo.com.br; diana@marinatecnologia.com.br.

${ }^{3}$ Federal University of Rio Grande do Sul - UFRGS. 00009428@ufrgs.br.
}

\begin{abstract}
The large amount of rice produced in Brazil generates a large volume of co-products, such as, Rice Husk (RH) and Rice Husk Ash (RHA). These co-products have amounts of silicon ( $\mathrm{Si}$ ) present in their structure, which can be used to synthesize silica-based materials as zeolites and MCM-type structures. The synthesis of MCM-48 material was carried out at room temperature, using the ionic liquid $\left[\mathrm{C}_{16} \mathrm{MI} \cdot \mathrm{Cl}\right]$ as structure-directing agent, depositing the niobium in situ during the synthesis with different molar ratios of $\mathrm{Si} / \mathrm{Nb}$ $(5,20,50$ and 80$)$. The material obtained was subjected to characterization by X-Ray Diffraction (XRD), Nitrogen Adsorption/Desorption isotherms and Scanning Electron Microscopy (SEM). The results confirm the formation of $\mathrm{Nb} / \mathrm{MCM}-48$ materials, in which their properties are consistent with those described in the literature. The deposition of $\mathrm{Nb}$ on MCM-48 did not change its structural properties, such as specific surface area and pore distribution for $\mathrm{Si} / \mathrm{Nb}$ higher than 5 . The results obtained demonstrate the success in the synthesis of mesoporous materials $\mathrm{Nb} / \mathrm{MCM}-48$ using industrial residues of rice as an alternative source of silicon, and in situ deposition of the niobium metal on the structure.
\end{abstract}


Victor de Aguiar Pedott - lemedelais Bordin - Carolina Elisa Demaman Oro - Ricardo Jorge Macieski - Diego Ivan Petkowicz Diana Exenberger Finkler - Rogério Marcos Dallago - João Henrique Zimnoch dos Santos - Marcelo Luis Mignoni

Keywords: One-Pot synthesis. MCM-48. Silicon. RHA. Niobium. mesoporous materials.

RESUMO: Grandes quantidades de arroz são produzidas no Brasil, gerando coprodutos, como a Casca de Arroz (CA) e as Cinzas da Casca de Arroz (CCA). O silício contido nestes coprodutos podem ser utilizados na síntese de materiais à base de silício, como zeólitas e estruturas do tipo MCM. A síntese do material $\mathrm{Nb} / \mathrm{MCM}-48$ ocorreu à temperatura ambiente, usando o líquido iônico $\left[\mathrm{C}_{16} \mathrm{MI} \cdot \mathrm{Cl}\right]$ como agente direcionador de estrutura, depositando o nióbio in situ durante a síntese com diferentes relações molares de $\mathrm{Si}$ / $\mathrm{Nb}(5,20,50$ e 80$)$. O material obtido ao final do processo foi submetido à caracterização pelas técnicas de Difração de Raios X (DRX), isotermas de adsorção/dessorção de nitrogênio $\left(\mathrm{N}_{2}\right)$ e Microscopia Eletrônica de Varredura (MEV). As análises confirmaram a obtenção do material Nb/MCM-48, onde suas propriedades condizem com as descritas na literatura. A deposição do Nb sobre a MCM-48 não alterou suas propriedades estruturais, como área superficial específica e distribuição de poros para relações molares maiores que 5. Os resultados obtidos demonstram o sucesso na síntese dos materiais mesoporosos Nb/MCM-48 utilizando resíduos da indústria de arroz como fonte alternativa de silício e na deposição in situ do metal nióbio sobre a estrutura.

Palavras-chave: Síntese Direta. MCM-48, Silício. CCA. Nióbio. Materiais Mesoporosos.

\section{Introduction}

Rice is among the five most productive crops in the world, in which its annual production is around 700 million tons (FAO, 2019). However, $20 \%$ of rice weight is Rice Husk (RH) (NATARAJAN; NORDIN; RAO, 1998), which is a co-product for industry, used as biomass fuel, generating energy through burning, replacing fossil fuels, and decreasing the $\mathrm{CO} 2$ emission (HUANG; LO, 2019). In this process, RH generates Rice Husk Ash (RHA) as residue, which contains a significant amount of silicon on its composition (BHAGIYALAKSHMI et al., 2010). The RHA includes $85 \%$ to $98 \%$ of amorphous silica on its composition when obtained from a controlled burning process (ENZWEILER; BARBOSA-COUTINHO; SCHWAAB, 2013).
Countless materials use silicon as the main element for the formation of their structures, like zeolites, mesoporous silicas and M41S materials. Typically, for the synthesis of silica-based materials, silicon commercial sources as Tetraethyl Orthosilicate (TEOS), Tetramethylammonium silicate (TMA-silicate), Tetramethyl Orthosilicate (TMOS), sodium silicate and amorphous silica are used, in which most of these precursors are expensive for industrial uses (BAŞGÖZ; GÜLER, 2020; BRINKER; SCHERER, 1990; HSIEH et al., 2017; SHAH et al., 2017). The application of alternative silica sources in the synthesis of silica-based materials decreases production costs and enables the utilization of residues. Different alternative sources of silica have been used by the scientific community in material synthesis, as RHA, coal fly ash, and residues from the sugar industry (BRAGA et al., 2013; MILLER; CUNNIN- 
GHAM; HARVEY, 2019; MISRAN et al., 2007; SOUZA et al., 2011).

Materials from M41S family, first reported by Mobil Oil Company (1992) (CHU et al., 1992), embraces three different structures MCM-41, MCM-48 and MCM-50, in which MCM-48 has cubic three dimensional structure, MCM-41 has a hexagonal two-dimensional structure and MCM-50 have lamellar structure (KUMAR et al., 2001; VARTULI et al., 1998). Normally, MCM-type materials are synthesized under hydrothermal procedures. However, these structures can be achieved at room temperature using surfactants as structure-directing agents (KUMAR et al., 2001).

Ionic liquids act as surfactants and structure-directing agents in the synthesis of MCM-type materials through the formation of extended hydrogen bond system in the liquid state (ANTONIETTI et al., 2004). The substitution of commonly used structure-directing agents as cetyltrimethylammonium bromide $(\mathrm{CTABr})$ and tetramethylammonium chloride (TMACl) is interesting due to low vapour pressure of ionic liquids, which decreases the emission of VOCs into the atmosphere (ANTONIETTI et al., 2004; AVELLANEDA et al., 2009)

The synthesis of MCM-type materials using alternative silica sources and ionic liquids as structure-directing agents through one-pot synthesis have a great application potential, reducing costs process steps (ARNALDO; COSTA, 2019; BHAGIYALAKSHMI et al., 2010; LOVELL et al., 2014; MISRAN et al., 2007; TEMPELMAN et al., 2016). MCM-48 properties, such as high thermal stability, high surface area, and three-dimensional structure, allows its application in catalysis fields as a support for different materials (HAZARIKA; BARMAN, 2019; LI et al., 2018; ROMERO et al., 2019; SHABAN; ABUKHADRA; HAMD, 2018; TAVAKOLI; MAMAGHANI, 2019).
The niobium is a transition metal with a significant occurrence in the Brazilian territory, and its major application is in the steel industry (ALVES; COUTINHO, 2019). Supported niobium in mesoporous materials could originate a new field of application improving both support and metal properties (FERREIRA et al., 2018; KAO et al., 2020; MÉNDEZ et al., 2017). Niobium has high thermal stability and shows strong metal-support interaction, which justifies its application in catalysis field (LI et al., 2020; PADULA et al., 2020; PERCIANI et al., 2018; SCALDAFERRI; MÁRCIA; PASA, 2019; SHEN et al., 2019; SKRODCZKY et al., 2019; YANG et al., 2019).

Given the above, the present work aimed to obtain through one-pot synthesis $\mathrm{Nb}$ / MCM-48 mesoporous materials at room temperature using rice industry waste as an alternative silicon source using different molar $\mathrm{Si} / \mathrm{Nb}$ ratios $(5,20,50$, and 80$)$.

\section{Materials and Methods}

\section{Materials}

The chemicals used for Nb/MCM-48 synthesis were: RHA provided by Marina Tecnologia LTDA (Brazil), sodium hydroxide (Vetec), hydrochloric acid (Quimex) ethanol (Synth), ammoniacal niobium oxalate ( $\mathrm{NH} 4[\mathrm{NbO}(\mathrm{C} 2 \mathrm{O} 4) 2(\mathrm{H} 2 \mathrm{O}) 2])$, and the ionic liquid 1-hexadecyl-3-methylimidazolium chloride $[\mathrm{C} 16 \mathrm{MI} \cdot \mathrm{Cl}]$ as structure-directing agent. In order to synthesize the ionic liquid, it was used ethyl acetate (Vetec), acetonitrile (Vetec), chlorohexadecane (Sigma Aldrich), and methyl-imidazole (Sigma Aldrich).

\section{Silica extraction from rice husk ash}

The methodology used for the removal of impurities from RHA was carried out as described by Kalapathy et al. (2000). Firstly, the 
RHA was washed using deionized water to remove impurities followed by filtration and then dried at $100{ }^{\circ} \mathrm{C}$ for 3 h. $30 \mathrm{~g}$ of the washed RHA was submitted to calcination ( 500 ${ }^{\circ} \mathrm{C}$ during $16 \mathrm{~h}$ ), followed by acid wash with $300 \mathrm{~mL}$ of distilled water with $\mathrm{pH}$ previously adjusted to 1 with $\mathrm{HCl}(6 \mathrm{~mol} / \mathrm{L})$. The acid wash was carried out under magnetic stirring at boiling temperature for $2 \mathrm{~h}$. Afterward, the residual material was filtered and dried.

After thermal and acid treatments, the silicon was extracted from $25 \mathrm{~g}$ of rice husk ash with $250 \mathrm{~mL}$ of $\mathrm{NaOH}(2 \mathrm{~mol} / \mathrm{L})$ in a reflux system for $4 \mathrm{~h}$, resulting in a $0.6 \mathrm{~mol} / \mathrm{L}$ $\mathrm{Na} 2 \mathrm{SiO} 3$ solution that was filtered and stored for further utilization. The residual rice husk ash was dried and weighed to evaluate extraction yield.

\section{Synthesis of Nb/MCM-48}

The methodology proposed by Kumar and collaborators (2001) for the synthesis of MCM-48 materials was carried out with some modifications. The synthesis proceeded in acid environment in which firstly 2.4 $\mathrm{g}$ of $\mathrm{C} 16 \mathrm{MI} \cdot \mathrm{Cl}$ was dissolved in a $100 \mathrm{~mL}$ solution $(50 \mathrm{~mL}$ of distilled water and 50 $\mathrm{mL}$ of ethanol), then, $10 \mathrm{~mL}$ of ammonium hydroxide (NH4OH) was added to the solution and submitted to magnetic stirring for 10 min. After homogenization, the solution was acidified $(\mathrm{pH}=1)$ with $\mathrm{HCl} 6 \mathrm{M}$ and finally, $27 \mathrm{~mL}$ of $0.6 \mathrm{M} \mathrm{Na} 2 \mathrm{SiO} 3$ were added under vigorous stirring. The reaction was carried out under magnetic stirring at room temperature for $2 \mathrm{~h}$, and the obtained material was then filtered and washed with distilled water.

For Nb/MCM-48 synthesis, Nb2O5 was used as $\mathrm{Nb}$ source, originated from calcination of ammoniacal niobium oxalate $(\mathrm{NH} 4[\mathrm{NbO}(\mathrm{C} 2 \mathrm{O} 4) 2(\mathrm{H} 2 \mathrm{O}) 2] \mathrm{H} 2 \mathrm{On})$ in muffle (Fornitec F3 - DM/T), following the heating ramp: $150{ }^{\circ} \mathrm{C}$ for $90 \mathrm{~min}$, and $450{ }^{\circ} \mathrm{C}$ for $360 \mathrm{~min}$, with a heating rate of $3{ }^{\circ} \mathrm{C} / \mathrm{min}$.
The $\mathrm{Nb}$ source was added simultaneously with $\mathrm{Na} 2 \mathrm{SiO} 3$ solution at different $\mathrm{Si} / \mathrm{Nb}$ molar ratios (5, 20, 50, and 80). Different proportions of niobium were used to verify its influence on structure and synthesis of $\mathrm{Nb}-\mathrm{MCM}-48$ using $\mathrm{Na} 2 \mathrm{SiO} 3$ as silica source.

\section{Equipment and characterization}

$\mathrm{X}$-ray diffraction analyses (XRD) were performed on a Rigaku Miniflex II Desktop $X$-Ray Diffraktometer diffractometer with $\mathrm{CuK} \alpha$ radiation $(\lambda=1.54 \AA)$. The Zeiss scanning electron microscope (model EVO LS25) with metallizer (QUORUM SC7620) was used for the Scanning Electron Microscopy (SEM). The samples were covered with 20 $\mathrm{nm}$ gold for the SEM images.

Textural Nitrogen (N2) adsorption/ desorption analysis (Quantachrome NOVA 2200e) were performed at a constant temperature of $-196^{\circ} \mathrm{C}(77 \mathrm{~K})$. The specific surface areas were determined using the BET method (BRUNAUER; EMMETT; TELLER, 1938).

\section{Results and Discussion}

\section{Silica extraction from RHA}

RHA was submitted to both thermal and acid treatments for silicon extraction through alkaline treatment. The thermal treatment (calcination) resulted in a decrease of $12 \%$ of sample mass, referring to organic matter and water. In the acid treatment, was observed a decrease of $2 \%$ referring to minerals contained in the sample, as described in literature (KALAPATHY; PROCTOR; SHULTZ, 2000). The resulting material was subjected to silica extraction using sodium hydroxide ( $2 \mathrm{M}$ ), in which a decrease of $60 \%$ of sample mass was observed, related to the $\mathrm{SiO} 2$ that interacted with the $\mathrm{NaOH}$, originating the $\mathrm{Na} 2 \mathrm{SiO} 3$ solution.

The acidification of the $\mathrm{Na} 2 \mathrm{SiO} 3$ solution causes precipitation of pure silica, which 
can be analysed through XRD analysis, as represented in Figure 1. The diffractogram represents an amorphous pattern for the precipitated silica along with peaks related to cristobalite ( 32 and $\sim 452 \theta$ degrees) (NAYAK; NANDI; DATTA, 2019), such patterns are characteristic of silica obtained from RHA.

Figure 1 - XRD diffractogram for the precipitate silica

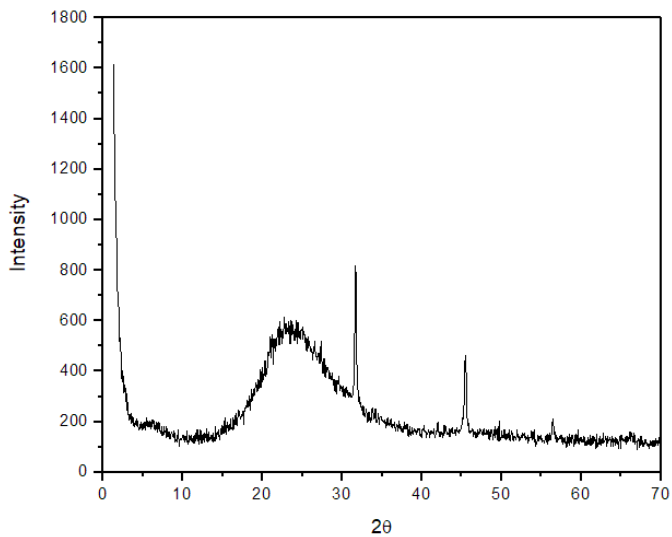

\section{Nb-MCM-48 materials}

To obtain the MCM-48 material, using $\mathrm{Na} 2 \mathrm{SiO} 3$ as silica source, the synthesis was carried out in acid media at room temperature, in which the silicon is found on precipitated form, enabling the material formation, as shown in Figure 2.

The XRD pattern confirms the formation of the MCM-48 material, due to low angle peaks between $2-52 \theta$ degrees followed by an amorphous part, a characteristic pattern for MCM-48 materials (KUMAR et al., 2001).

The $\mathrm{Nb}$ incorporation on MCM-48 materials was carried out using niobium oxide $(\mathrm{Nb} 2 \mathrm{O} 5)$, and the obtained results are shown in Figure 3.

Analyzing the diffractogram of Figure 3 (a) related to the $\mathrm{Nb2O}$, it is possible to notice the peaks characteristic to the orthorhom-
Figure 2 - MCM-48 XRD pattern using acid media for the synthesis

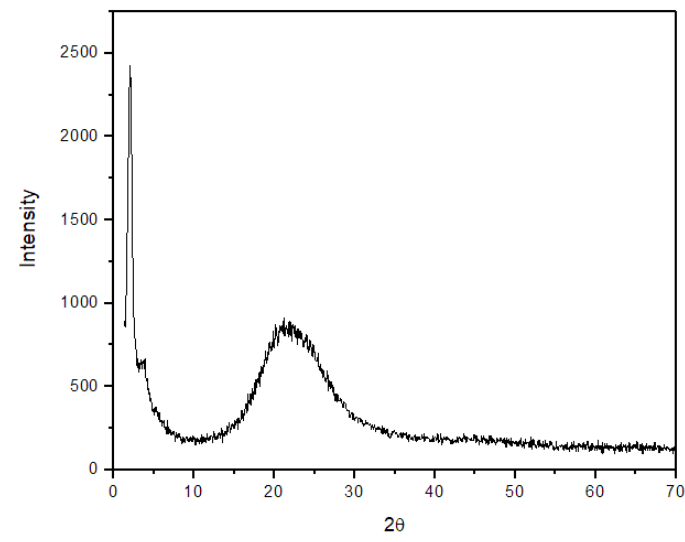

Figure 3 - Diffractograms for $\mathrm{Nb} / \mathrm{MCM}-48$ materials, in which (a) represents the pure $\mathrm{Nb} 2 \mathrm{O} 5$, (b) $\mathrm{Si} / \mathrm{Nb}=5$, (c) $\mathrm{Si} /$ $\mathrm{Nb}=20,(\mathrm{~d}) \mathrm{Si} / \mathrm{Nb}=50$ and (e) $\mathrm{Si} / \mathrm{Nb}=80$

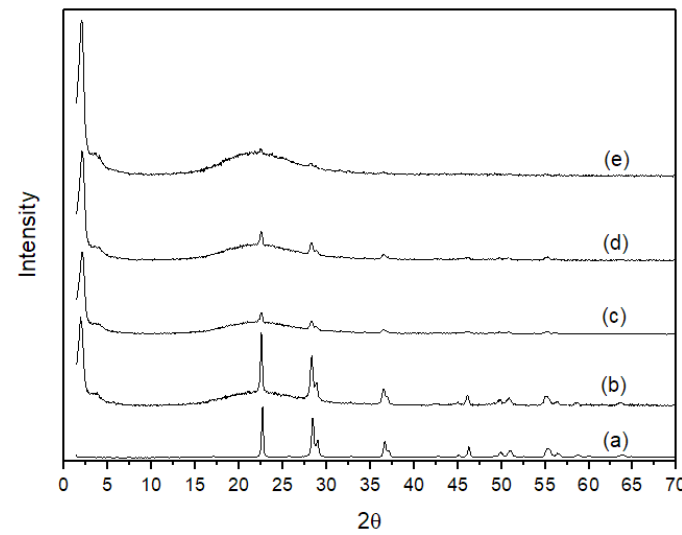

bic phase structure of $\mathrm{Nb} 2 \mathrm{O} 5$, formed when the material was subjected to calcination at temperatures between $450{ }^{\circ} \mathrm{C}$ and $700{ }^{\circ} \mathrm{C}(\mathrm{R}$. P. P. ROMERO; P. C. PANTA, 2016). The patterns related to $\mathrm{Nb} 2 \mathrm{O} 5$ also appears in the diffractograms of synthesized $\mathrm{Nb} / \mathrm{MCM}-48$ materials, suggesting that $\mathrm{Nb}$ particles are externally deposited on MCM-48 structure, in which a small amount of $\mathrm{Nb}$ has possibly been incorporated into the material network, however, more characterization techniques are needed to prove the $\mathrm{Nb}$ incorporation into the material network. At low $\mathrm{Si} / \mathrm{Nb}$ ratios the 
$\mathrm{Nb} 2 \mathrm{O} 5$ peaks appear with more intensity, due to higher concentrations of the material and for higher ratios of $\mathrm{Si} / \mathrm{Nb}$ a decrease in the peaks intensity is seen.

\section{Nitrogen (N2) adsorption/desorption Isotherms}

The Nb/MCM-48 materials with different $\mathrm{Si} / \mathrm{Nb}$ ratios were submitted to nitrogen adsorption/desorption analysis in order to verify the superficial and porous characteristics of the materials. Initially, the pure MCM-48 material was analyzed, so the resulting isotherm is shown in Figure 4.

The obtained MCM-48 isotherms are related to IV(a) type, characteristic of materials from M41S family (JANG et al., 2009) in which the pattern corresponds to materials with mesoporous structures (THOMMES et al., 2015). The phenomenon of condensation and evaporation cause the formation of H1 type hysteresis for MCM-48 materials, indicating the presence of pores with open cylindrical channels of uniform size and shape (THOMMES et al., 2015).

Figure 4 - Adsorption $(\bullet) /$ desorption $(\boldsymbol{\Delta})$ isotherm for pure MCM-48

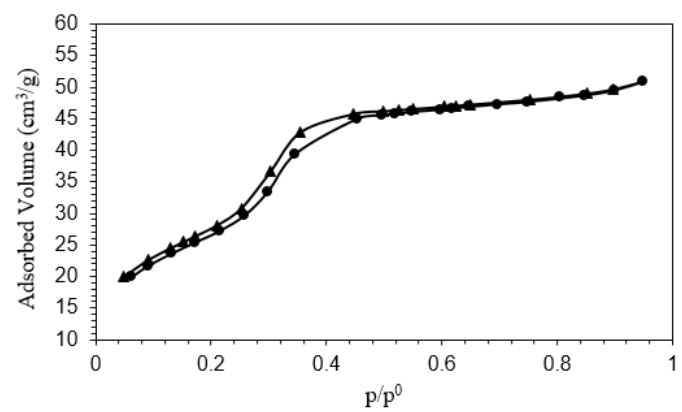

The $\mathrm{Nb} / \mathrm{MCM}-48$ materials with different molar ratios were also analyzed, the results are shown in Figure 5.

It is possible to notice that $\mathrm{Nb} / \mathrm{MCM}-48$ materials with different molar ratios maintained both isotherms and hysteresis patterns.

Figure 5 - Adsorption $(\bullet) /$ desorption $(\boldsymbol{\Delta})$ isotherms for Nb/MCM-48 materials with different molar ratios, where (a) $\mathrm{Si} / \mathrm{Nb}=$ 5 , (b) $\mathrm{Si} / \mathrm{Nb}=20$, (c) $\mathrm{Si} / \mathrm{Nb}=50$ and (d) $\mathrm{Si} / \mathrm{Nb}=80$
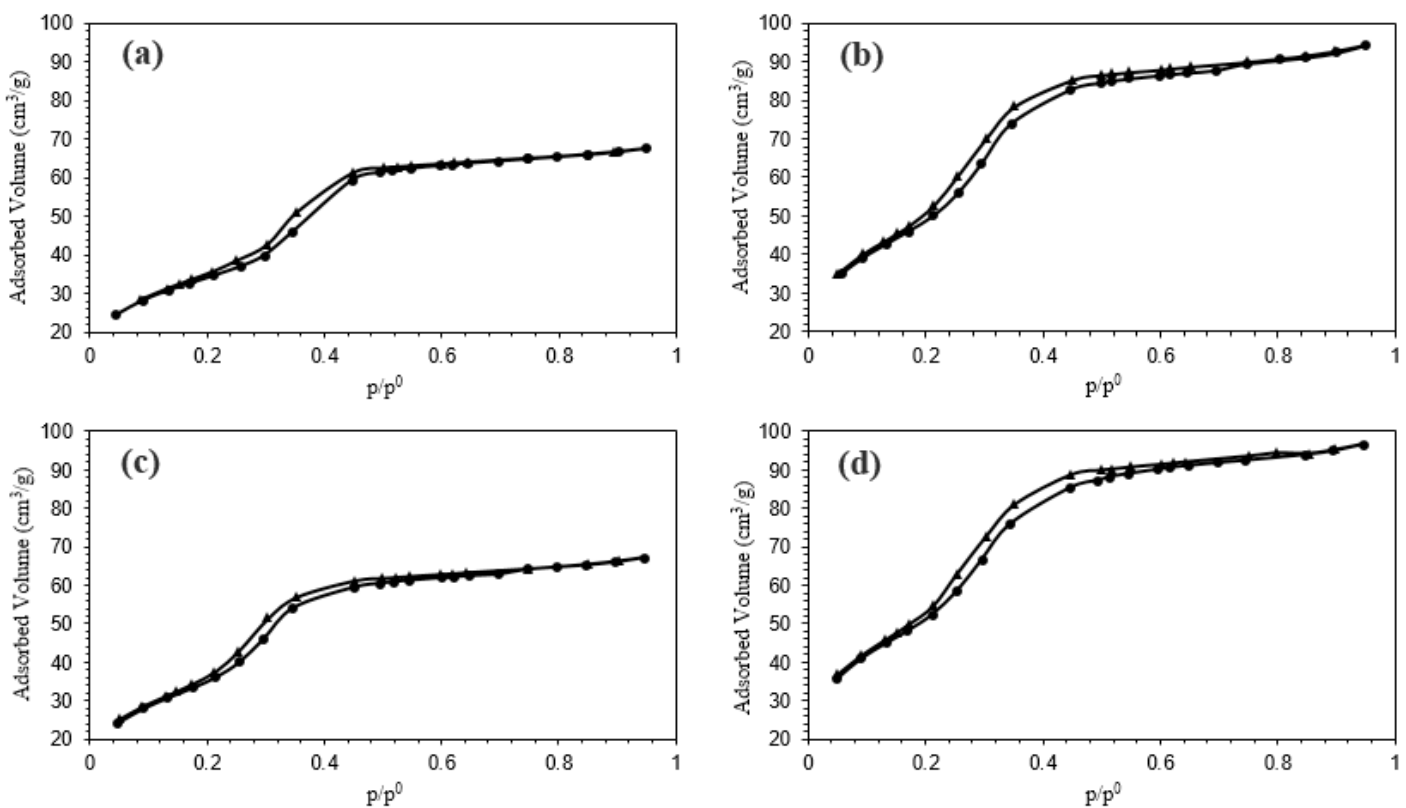
Therefore, $\mathrm{Nb}$ incorporation in the MCM-48 material does not modify the material structure, maintaining a mesoporous structure with cylindrical open pores.

The properties of the synthesized MCM48 along with $\mathrm{Nb} / \mathrm{MCM}-48$ materials with different molar ratios are shown in Table I.

Table I - Properties of MCM-48 and Nb/MCM-48 materials with different molar ratios

\begin{tabular}{ccc}
\hline Sample & $\begin{array}{c}\text { Surface } \\
\text { area } \\
\left(\mathrm{m}^{2} / \mathrm{g}\right)\end{array}$ & $\begin{array}{c}\text { Pore } \\
\text { volume } \\
\left(\mathrm{cm}^{3} / \mathrm{g}\right)\end{array}$ \\
\hline $\mathrm{MCM}-48$ & 960 & 0.33 \\
$\mathrm{Nb} / \mathrm{MCM}-48(\mathrm{Si} / \mathrm{Nb}=5)$ & 590 & 0.23 \\
$\mathrm{Nb} / \mathrm{MCM}-48(\mathrm{Si} / \mathrm{Nb}=20)$ & 953 & 0.33 \\
$\mathrm{Nb} / \mathrm{MCM}-48(\mathrm{Si} / \mathrm{Nb}=50)$ & 978 & 0.33 \\
$\mathrm{Nb} / \mathrm{MCM}-48(\mathrm{Si} / \mathrm{Nb}=80)$ & 944 & 0.33 \\
\hline
\end{tabular}

Data exposed in Table I shows that for higher molar ratios $(\mathrm{Si} / \mathrm{Nb}=20,50$, and 80$)$ the MCM-48 properties are maintained. However, for the molar ratio $\mathrm{Si} / \mathrm{Nb}=5 \mathrm{a}$ significant decrease in the surface area and pore volume was observed. That could be caused due to higher $\mathrm{Nb} 2 \mathrm{O} 5$ that blocks the pore channels, decreasing both surface area and pore volume (WACHS et al., 2000). The pore size remained the same for the different molar relations in the range of 2.2 to $3.2 \mathrm{~nm}$; such values are characteristic for MCM-48 materials (NASCIMENTO et al., 2014).

\section{Scanning Electron Microscopy (SEM)}

The obtained MCM-48 and Nb/MCM-48 materials using RHA as silicon source were submitted to Scanning Electron Microscopy (SEM) analysis to verify the material morphology (Figure 6).

As it is possible to be seen in Figure 6, the synthesized MCM-48 presented uniform spherical particles. This result agrees with those found in the literature for MCM-48 using commercial silicon sources (SCHUMACHER; GRÜN; UNGER, 1999).

When comparing the morphologies for both materials, it is possible to verify that the synthesized samples, with or without the addition of $\mathrm{Nb} 2 \mathrm{O} 5$, show similar morphologies, demonstrating that the $\mathrm{Nb} 2 \mathrm{O} 5$ does not influence the formation of MCM-48 morphology. In addition, the spherical format of the samples is characterized by the use of ionic liquids as structure-directing agents. All obtained materials are similar to pure MCMs as shown in the literature (BREVET et al., 2016).

Figure 6: Morphology of the obtained materials: (a) MCM-48 using RHA as silicon source and (b) $\mathrm{Nb} / \mathrm{MCM}-48$ with $\mathrm{Si} / \mathrm{Nb}=5$

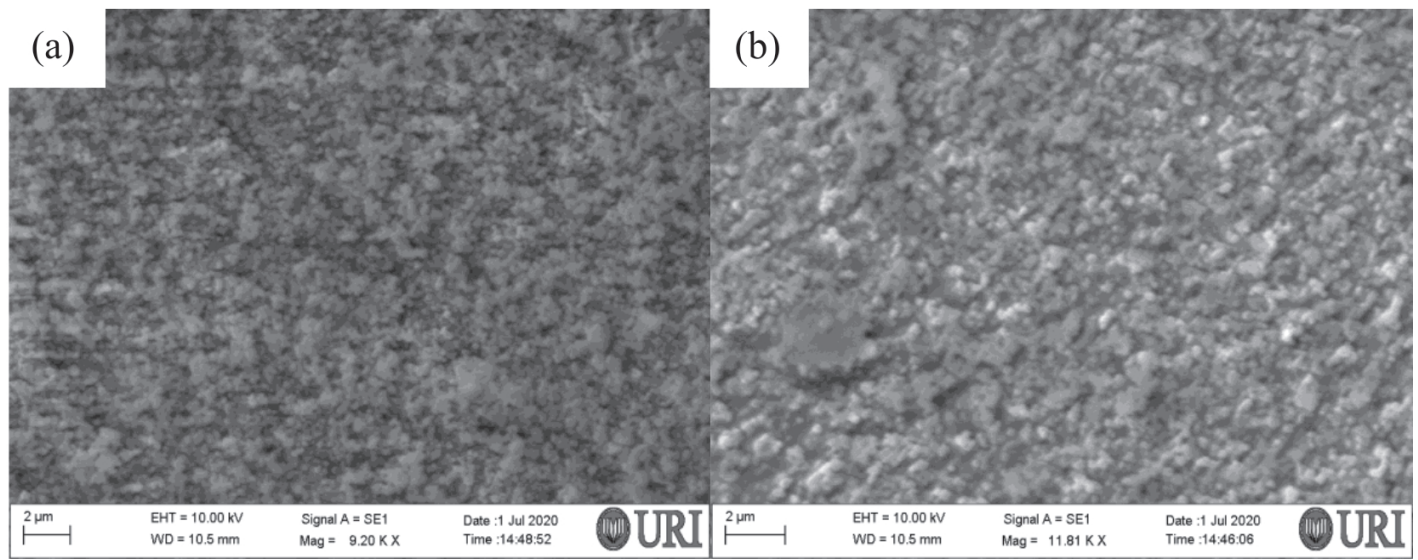




\section{Conclusion}

Through the exposed results, it is possible to conclude that the utilization of residues with high concentrations of silicon, as the RHA is a viable source of $\mathrm{Na} 2 \mathrm{SiO} 3$ for the one-pot synthesis of $\mathrm{Nb} / \mathrm{MCM}-48$ materials at room temperature. The incorporation of small amounts of $\mathrm{Nb}$ to MCM-48 materials does not affect its structure. Therefore, it is possible to combine the properties of MCM48 and $\mathrm{Nb}$ materials, creating a new field of application for these materials.

\section{ACKNOWLEDGMENTS}

The authors thank URI Erechim, National Council for Scientific and Technological Development (CNPq), Coordination for the Improvement of Higher Education Personnel (CAPES) and Research Support Foundation of the State of Rio Grande do Sul (FAPERGS).

\section{REFERENCES}

ALVES, A. R.; COUTINHO, A. R. Life cycle assessment of niobium: A mining and production case study in Brazil. Minerals Engineering, v. 132, n. 38, p. 275-283, 2019.

ANTONIETTI, M.; KUANG, D.; SMARSLY, B.; ZHOU, Y. Ionische Flüssigkeiten für die Synthese funktioneller Nanopartikel und anderer anorganischer Nanostrukturen. Angewandte Chemie, v. 116, n. 38, p. 5096-5100, 2004.

ARNALDO, J.; COSTA, S. Use of Ionic Liquid as Template for Hydrothermal Synthesis of the MCM-41 Mesoporous Material. C. M. Silicon, v. 11, n. 21 p. 1-6, 2019.

AVELLANEDA, R. S.; IVANOVA, S.; SANZ, O.; ROMERO-SARRIA, F.; CENTENO, M. A.; ODRIOZOLA, J. A. Ionic liquid templated $\mathrm{TiO} 2$ nanoparticles as a support in gold environmental catalysis. Applied Catalysis B: Environmental, v. 93, n. 2, p. 140-148, 2009.

BAŞGÖZ, Ö.; GÜLER, Ö. The unusually formation of porous silica nano-stalactite structure by high temperature heat treatment of $\mathrm{SiO} 2$ aerogel synthesized from rice hull. Ceramics International, v. 46, n. 1, p. 370-380, 2020.

BHAGIYALAKSHMI, M.; YUN, L. J.; ANURADHA, R.; JANG, H. T. Utilization of rice husk ash as silica source for the synthesis of mesoporous silicas and their application to CO 2 adsorption through TREN / TEPA grafting. Journal of Hazardous Materials, v. 175, n. 12, p. 928-938, 2010.

BRAGA, R. M.; TEODORO, N. M.; AQUINO, F. M.; BARROS, J. M. F.; MELO, D. M. A.; FREITAS, J. C. O. Síntese da peneira molecular MCM-41 derivada da cinza da casca de arroz. Holos, v. 5, n. 42 p. 40-49, 2013.

BREVET, D.; JOUANNIN, C.; TOURNÉ-PÉTEILH, C.; DEVOISSELLE, J. M.; VIOUX, A.; VIAU, L. Self-encapsulation of a drug-containing ionic liquid into mesoporous silica monoliths or nanoparticles by a sol-gel process. Royal Society of Chemistry, v. 6, n. 86, p. 82916-82923, 2016.

BRINKER, C. J.; SCHERER, G. W. Sol-Gel Science: The Physics and Chemistry of Sol-Gel

Processing. San Diego, CA: Harcourt Brace Jovanovic, Publishers, 1990. 
BRUNAUER, S.; EMMETT, P. H.; TELLER, E. Adsorption of Gases in Multimolecular Layers. Journal of the American Chemical Society, v. 60, n. 2, p. 309-319, 1938.

CHU, K. D. S. C. T.; SHEPPARD, D. H. O. E W; HIGGINS, J. B.; SCHLENKER, J. L. A New Family of Mesoporous Molecular Sieves Prepared with Liquid Crystal Templates. American chemical Society, v. 114, n. 14, p. 10834-10843, 1992.

ENZWEILER, H.; BARBOSA-COUTINHO, E.; SCHWAAB, M.. Cinzas de casca de arroz como fonte alternativa de silício para a síntese de zeólita beta. Revista do centro de Ciências Naturais e Exatas - UFSM, v. 17, n. 8, p. 3284-3292, 2013.

FAO. World Food and Agriculture - Statistical Pocketbook 2019. 2019th ed. Rome: Organization of the United Nations (FAO), 2019.

FERREIRA, C.; ARAUJO, A.; CALVINO-CASILDA, V.; CUTRUFELLO, M. G.; ROMBI, E.; FONSECA, A. M.; BAÑARES, M. A.; NEVES, I. C. Y zeolite-supported niobium pentoxide catalysts for the glycerol acetalization reaction. Microporous and Mesoporous Materials, v. 271, n.15, p. 243-251, 2018.

HAZARIKA, S.; BARMAN, P. Ultrasound Assisted Solvent / Metal Free Synthesis of 3-Sulfenylindoles Employing TBATB-Grafted MCM-48 as a suitable Heterogeneous Catalyst. Chemistry Select, v. 4, n. 9, p. 7082-7089, 2019.

HSIEH, Y. Y.; TSAI, Y. C.; HE, J. R.; YANG, P. F.; LIN, H. P.; HSU, C. H.; LOGANATHAN, A. Rice husk agricultural waste-derived low ionic content carbon-silica nanocomposite for green reinforced epoxy resin electronic packaging material. Journal of the Taiwan Institute of Chemical Engineers, v. 78, n. 58. p. 493-499, 2017.

HUANG, Y.; LO, S. Utilization of rice hull and straw. In: ELSELVIER INC. Rice. 4th ed. Elsevier Inc. in cooperation with AACC International, 2019. p. 627-661.

JANG, H. T.; PARK, Y. K.; KO, Y. S.; LEE, Ji Y.; MARGANDAN, B. Highly siliceous MCM-48 from rice husk ash for $\mathrm{CO} 2$ adsorption. International Journal of Greenhouse Gas Control, v. 3, n. 5, p. 545-549, 2009.

KALAPATHY, U; PROCTOR, A; SHULTZ, J. A simple method for production of pure silica from rice hull ash. Bioresource technology, v. 73, n. 24, p. 257-262, 2000.

KAO, L. C.; KAN, W. C.; MARTIN-ARANDA, R. M.; GUERRERO-PEREZ, M. O.; BAÑARES, M.; LIOU, S. Y. H. SiO2 supported niobium oxides with active acid sites for the catalytic acetalization of glycerol. Catalysis Today, v. 356, n. 8, p. 80-87, 2020.

KUMAR, D.; SCHUMACHER, K.; DU FRESNE VON HOHENESCHE, C.; GRÜN, M.; UNGER, K. K. MCM-41, MCM-48 and related mesoporous adsorbents: their synthesis and characterisation. Colloids and Surfaces A: Physicochemical and Engineering Aspects, v. 187-188, n. 26, p. 109116, 2001.

LI, S.; LUO, Z.; WANG, W.; SUN, H.; XIE, J.; LIANG, X. Bioresource Technology Catalytic fast pyrolysis of enzymatic hydrolysis lignin over Lewis-acid catalyst niobium pentoxide and mechanism study. Bioresource Technology, v. 316, n. 5, p. 115-128, 2020.

LI, X.; CHEN, W.; TANG, Y.; LI, L. Chemosphere Relationship between the structure of FeMCM-48 and its activity in catalytic ozonation for diclofenac mineralization. Chemosphere, v. 206, n.42, p. 615-621, 2018.

LOVELL, E.; JIANG, Y.; SCOTT, J.; WANG, F.; SUHARDJA, Y.; CHEN, M.; HUANG, J.; AMAL, R. CO2 reforming of methane over MCM-41-supported nickel catalysts: Altering support acidity by one-pot synthesis at room temperature. Applied Catalysis A: General, v. 473, n. 84, p. 51-58, 2014. 
Victor de Aguiar Pedott - lemedelais Bordin - Carolina Elisa Demaman Oro - Ricardo Jorge Macieski - Diego Ivan Petkowicz Diana Exenberger Finkler - Rogério Marcos Dallago - João Henrique Zimnoch dos Santos - Marcelo Luis Mignoni

MÉNDEZ, F. J.; FRANCO-LÓPEZ, O. E.; BOKHIMI, X.; SOLÍS-CASADOS, D. A.; ESCOBARALARCÓN, L.; KLIMOVA, T. E. Dibenzothiophene hydrodesulfurization with NiMo and CoMo catalysts supported on niobium-modified MCM-41. Applied Catalysis B: Environmental, v. 219, n. 62 p. 479-491, 2017.

MILLER, S. A.; CUNNINGHAM, P. R.; HARVEY, J. T. Rice-based ash in concrete: A review of past work and potential environmental sustainability. Resources, Conservation and Recycling, v. 146, n. 5, p. 416-430, 2019.

MISRAN, H.; SINGH, R.; BEGUM, S.; YARMO, M. A. Processing of mesoporous silica materials (MCM-41) from coal fly ash. Journal of Materials Processing Technology, v. 186, n. 3, p. 8-13, 2007.

NASCIMENTO, A. R.; FIGUEREDO, G. P; RODRIGUES, G; MELO, M. A. F.; SOUZA, M. J. B.; MELO, D. M. A.; ELZE, J. R. Síntese e caracterização de materiais mesoporosos modificados com níquel para a captura de CO 2. Cerâmica, v. 60, n.16, p. 482-489, 2014.

NATARAJAN, E.; NORDIN, A.; RAO, A. N. Overview of combustion and gasification of rice husk in fluidized bed reactors. Biomass and Bioenergy, v. 14, n. 5-6, p. 533-546, 1998.

NAYAK, P. P.; NANDI, S.; DATTA, A. K. Comparative assessment of chemical treatments on extraction potential of commercial grade silica from rice husk. Engineering Reports, v. 1, n. 2, p. $1-13,2019$.

PADULA, I. D.; SANTOS, B. M. A.; RODRIGUES, A. P. H.; LANA, P.; MENDES, I. M. C.; PORTILHO, M. F.; OLIVEIRA, L. C. A.; OLIVEIRA, C. C. General Niobium-modified hydrotalcite catalysts : Sustainable conversion of waste glycerol to valuable chemicals. Applied Catalysis A, v. 606, n. 4, p. 112-118, 2020.

PERCIANI, N.; MORAES, D.; NASCIMENTO, F.; LUCIA, M.; PINTO, C.; MOREIRA, T.; CAMPOS, B.; PATROCÍNIO, G.; ALVARES, L. Methylene blue photodegradation employing hexagonal prism- shaped niobium oxide as heterogeneous catalyst : Effect of catalyst dosage, dye concentration, and radiation source. Materials Chemistry and Physics, v. 214, n. 8, p. 95-106, 2018 .

R. P. P. ROMERO; P. C. PANTA, A. O. de Araújo; C. P. Bergmann. Estudo da morfologia do pentóxido de nióbio. Congresso Brasileiro de Engenharia e Ciência dos Materiais, v. 11, n. 31, p. $2-5,2016$.

ROMERO, A.; NIETO-MÁRQUEZ, A.; ESSAYEM, N.; ALONSO, E.; PINEL, C. Microporous and Mesoporous Materials Improving conversion of D -Glucose into short-chain alkanes over R U / MCM- 48 based catalysts. Microporous and Mesoporous Materials, v. 286, n. may, p. 25-35, 2019.

SCALDAFERRI, C. A.; MÁRCIA, V.; PASA, D. Production of jet fuel and green diesel range biohydrocarbons by hydroprocessing of soybean oil over niobium phosphate catalyst. Fuel, v. 245, n. 5, p. 458-466, 2019.

SCHUMACHER, K.; GRÜN, M.; UNGER, K. K. Novel synthesis of spherical MCM-48. Microporous and Mesoporous Materials, v. 27, n. 3, p. 201-206, 1999.

SHABAN, M.; ABUKHADRA, M. R; HAMD, A. Recycling of glass in synthesis of MCM - 48 mesoporous silica as catalyst support for $\mathrm{Ni} 2 \mathrm{O} 3$ photocatalyst for Congo red dye removal. Clean Technologies and Environmental Policy, v. 20, n. 1, p. 13-28, 2018.

SHAH, B. A.; PATEL, A. V.; BAGIA, M. I.; SHAH, A. V. Green approach towards the synthesis of MCM-41 from siliceous sugar industry waste. International Journal of Applied Chemistry, v. 13, n. 3, p. 497-514, 2017. 
SHEN, Y.; ZHAO, B.; LIU, Q.; NAKANISHI, K.; CHEN, J.; KANAMORI, K.; WU, H.; HE, Z.; ZENG, M.; LIU, H. Macroporous Niobium Phosphate-Supported Magnesia Catalysts for Isomerization of Glucose-to-Fructose. ACS Sustainable Chemistry and Engineering, v. 7, n. 11, p. 8512-8521, 2019.

SKRODCZKY, K.; ANTUNES, M. M.; HAN, X.; SANTANGELO, S.; VALENTE, A. A.; PINNA, N.; RUSSO, P. A. Niobium pentoxide nanomaterials with distorted structures as efficient acid catalysts. Communications Chemistry, v. 129, n. 12, p. 1-11, 2019.

SOUZA, A. E.; TEIXEIRA, S. R.; SANTOS, G. T.A.; COSTA, F. B.; LONGO, E. Reuse of sugarcane bagasse ash (SCBA) to produce ceramic materials. Journal of Environmental Management, v. 92, n. 10, p. 2774-2780, 2011.

TAVAKOLI, F.; MAMAGHANI, M.. Introduction of Ag / CuO / MCM - 48 as an efficient catalyst for the one - pot synthesis of novel pyran - pyrrole hybrids. Wiley Applied Organometallic Chemistry, v. 33, n. 19, p. 1-16, 2019.

TEMPELMAN, C. H. L.; PORTILLA, M. T.; MARTÍNEZ-ARMERO, M. E.; MEZARI, B.; DE CALUWÉ, N. G. R.; MARTÍNEZ, C.; HENSEN, E. J. M. One-pot synthesis of nano-crystalline MCM-22. Microporous and Mesoporous Materials, v. 220, n. 9, p. 28-38, 2016.

THOMMES, M.; KANEKO, K.; NEIMARK, A. V.; OLIVIER, J. P.; RODRIGUEZ-REINOSO, F.; ROUQUEROL, J.; SING, K. S. W. Physisorption of gases, with special reference to the evaluation of surface area and pore size distribution (IUPAC Technical Report). Pure and Applied Chemistry, v. 87, n. 10, p. 1051-1069, 2015.

VARTULI, J.C.; ROTH, W. J.; BECK, J. S.; MCCULLEN, S. B.; KRESGE, C. T. The Synthesis and Properties of M41S. Molecular Sieves, v. 1, n. 51, p. 97-119, 1998.

WACHS, I. E.; CHEN, Y.; JEHNG, J. M.; BRIAND, L. E.; TANAKA, T. Molecular structure and reactivity of the Group V metal oxides. Catalysis Today, v. 78, n. 4, p. 13-24, 2000.

YANG, J.; MOHMAD, A. R.; WANG, Y.; FULLON, R.; SONG, X.; ZHAO, F.; BOZKURT, I.; AUGUSTIN, M.; SANTOS, E. J. G.; SHIN, H. S.; ZHANG, W.; VOIRY, D.; JEONG, H. Y.;

CHHOWALLA, M. Ultrahigh-current-density niobium disulfide catalysts for hydrogen evolution.

Nature Materials, v. 18, n. 5, p. 426-439, 2019. 
